\title{
CHAPTER 14 \\ LABORATORY STUDY OF SCALE EFFECTS IN TWO-DIMENSIONAL BEACH PROCESSES
}

\author{
Yurch 1 Iwagakn \\ Professor of Hydraulics \\ Disaster Prevention Research Institute \\ Kyoto University, Kyoto, Japan \\ and \\ Hideaki Noda \\ Assistant Professor of Hydraulics \\ Trainıng Institute for Engineerıng Teachers \\ Kyoto Unzversity, Uji Cıty, Kyoto, Japan
}

In order to disclose the essential relationship between the beach processes and wave characterıstics, two dimensional model tests are often performed for beach profile changes due to incldent breaknng waves normal to the beach. In applying the results of such experiments to the prototype of beaches, the scale effects of waves and sedıments on the beach processes with equilıbrium beach profiles should necessarıly be considered.

In this paper, as an approach to solve this problem in two dimensional beach studies, the effects of wave helght and sediment slze on the shore line movement and equilibrium beach profiles are discussed kased on the results of experiments made by the authors and other experıments with smaller and larger scales by some researchers. It has been found that the ratıo of wave height to sediment diameter is a very significant factor in this problem. In addition, the changes in a character of breaking waves during the tume period of wave action from the beach having an instial constant slope to that wsth an equilibrıum profile are presented.

\section{INIRODUCTION}

In order to understand correctly the problem of beach erosions, it is necessary to disclose the complicated phenomena of beach processes mainly by the wave action. In treating beach eroslon phenomena, a study should be made generally dzviding sediment transport into the following two modes: waves; and

1. Sand movement normal to the shore line by the direct action of

2. sand/ movement along the shore by currents due to breaking waves.

The sand movement in the first mode causes the beach process of a short period of time and it is well known that the characters of incident waves influence greatly this phenomenon. On the other hand, the sand movement in the second mode governs the beach process of a relatively long per1od of time which depends on an alongshore distribution of the littoral transport rate. From this point of view, many researches have been made at Kyoto University. Especlally much effort has been made in establishing the mechanics of the beach process not only by laboratory experiments but also by field observations, on the beach profile changes with the problem of equilibrium beach profiles for the first mode of sand movement (Hayami, I shihara and Iwagaki, 1953; Iwagaki and Sawarag1, 1955, 1956, 1958; Iwagakı and Noda, 


\section{LABORATORY STUDY OF SCALE EFFECTS IN TWO-DIMENSIONAL BEACH PROCESSES}

196la, 1961b) and on the estimation of the littoral transport rate as an approach to disclose the beach erosion mechanism for the second mode of sand movement (Sawaragi and Murakami, 1957; Iwagaki and Sawarag1, 1960)。 However, the method to analyze the beach process by observing under natural circumstances at actual beaches for the purpose of disclosing the beach erosion mechanism is generally not hopeful except under certaln limeted conditions because it is difficult to separate clearly the effects of main factors which influence this complicated phenomenon. Therefore, model experiments are often made considering hydraulic siml larity to some extent, and then various phenomena which occur at actual beaches are explained or predicted so that a counter-measure is established. Accordingly the most importance in such experıments is the problem of the simlarity between models and prototypes. The purpose of this paper is to discuss how the relative sizes of deep-water waves and sediments in addition to the deep-water wave steepness influence the two dimensional beach process due to the sand movement normal to the shore line and the equilibrium beach proflle, based on the results of experiments by the authors and other researchers.

A laboratory study for equilibrıum profiles of beaches by Johnson ( 1949) Indicated that the profile of a beach is changed with the value of the deep-water wave steepness $\mathrm{H}_{\mathrm{O}} / \mathrm{L}_{\mathrm{O}}$, and especially it is called the "normal" beach when the steepness is small and, on the other hand, the "storm" beach characterlzed by the appearance of longshore bars when the steepness is large, in which the critical wave steepness in deep-water for both is 0.025 to 0.030 . Iwagakn and Sawaragi $(1955,1956,1958)$ made experıments of equilibrium beach profiles and the sand movement due to breaking waves by using the sands of three different sizes. Kurihara and others (1956) and Shinohara and others (1958) compared the results of experiments by the pulverized coal having small specific gravity with those by the sand. In the United States of America, many experiments were made by Scott at the Unversity of Calıformia (1954), and Rector (1954), Watts (1954) and Saville (1957) at the Beach Erosion Board. These experiments showed that the storm beach is developed even when the deep-water wave steepnesses are 0.019 and 0.0064 according to the results by Scott and Saville respectively. Especially it should be noted that the results by Saville who made experiments with as large waves as at actual beaches are remarkably different from those with small waves. Accordingly it is presumed that such phenomena involving the sand movement have much scale effect, and this is a reason why the authors began such an investigation.

Since the scale effect on the beach process is also expected as well as on the equilibrium beach profile, the distance of shoreline movement when the beach having an $1 \mathrm{~m}$ tial constant slope is changed into the state of equilibrium is treated as an example, and the experıments are made in an effort to disclose the effects of the relative size of waves and sediments on the two dimensional beach process w1 th considerations for the equilibrium beach profile. In addztion, the changes in a character of breaking waves in the beach process from a uniform slope to an equilibrium state are reported.

\section{EQUIPMENTS AND PROCEDURES FOR EXPERIMENTS}

Laboratory experiments of beach processes have been made using a concrete wave tank $70 \mathrm{~m}$ long, $1.0 \mathrm{~m}$ wide and $1.5 \mathrm{~m}$ deep (Fig. la) and a steel wave tank $70 \mathrm{~m}$ long, $0.5 \mathrm{~m}$ wide and $0.6 \mathrm{~m}$ deep (F1g. 1b) at the Ujigawa Hy- 


\section{COASTAL ENGINEERING}

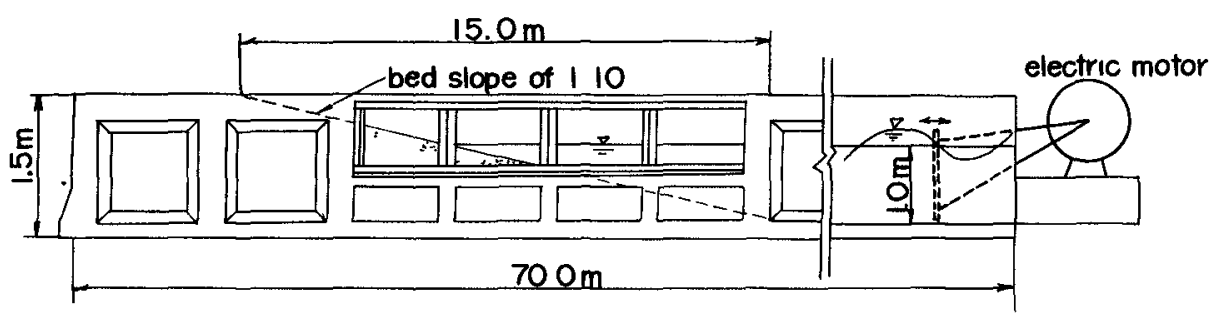

Fig. 1a. Schematic drawing of concrete wave tank.

\section{Plunger type wavegenerator}

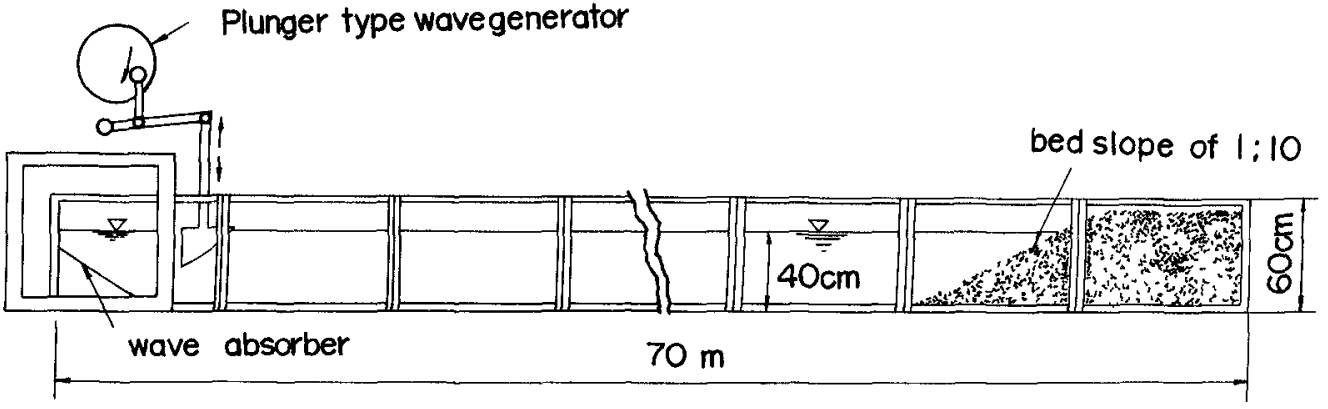

Fig. Ib. Schematic drawing of steol wave tank.

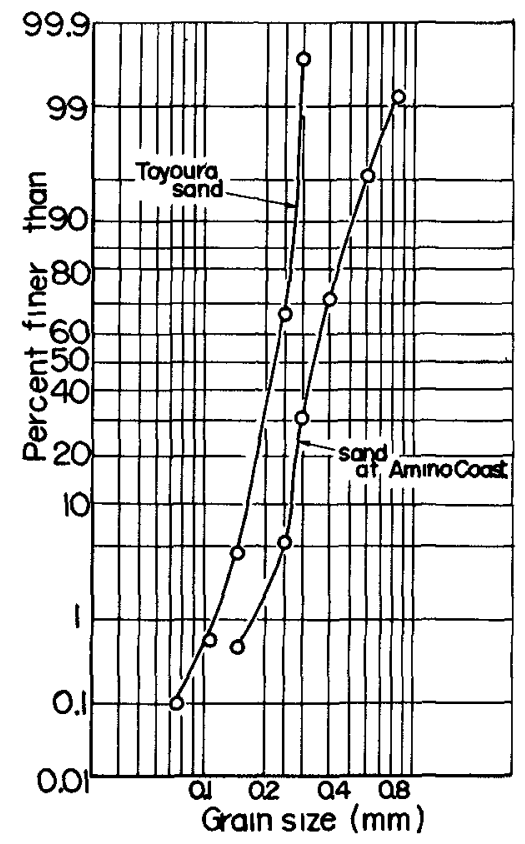

Fig. 2. Sleve analysts of sands used in the tests. 


\section{LABORATORY STUDY OF SCALE EFFECTS IN TWO-DIMENSIONAL BEACH PROCESSES}

draulıc Laboratory, Disaster Preventıon Research Institute, Kyoto Unıversıty. Some of the data were taken by dividing the beach in the concrete wave tank longitudinally into two parts and puttıng the sands of two drfferent sizes to find the effect of sand sizes on beach processes.

In the concrete wave tank waves are generated by a multı-purpose flatter type generator with a $10 \mathrm{HP}$ electric motor or by a pneumatic type wave generator with a $7.5 \mathrm{HP}$ blower. In the steel wave tank a plunger type wave generator with a $2 \mathrm{HP}$ electruc motor is installed.

Incident wave heights were measured by an electric point gage or an electric reslstance type wave gage with an inkwriting-oscillograph. Water depths tested were $1.0 \mathrm{~m}$ in the concrete wave tank and $0.4 \mathrm{~m} \mathrm{in} \mathrm{the} \mathrm{steel}$ wave tank.

Two kinds of sands used in the experıments were the well-sorted sand at Amino Coast and the standard sand by JIS, which is called Toyoura sand, with median diameters of $0.34 \mathrm{~mm}$ and $0.22 \mathrm{~mm}$ and specific gravities of 2,62 and 2.59 respectively (Fig, 2). The initial slope of the beaches constituted by these sands was 1 on 10 every time. Table 1 shows the characters of waves and sands used, the duration times of the experiments and the data obtained.

The profiles of beaches were measured by a point gage $15 \mathrm{~min}_{8} 30$ min, $1 \mathrm{hr}, 2 \mathrm{hrs}, \ldots . .$. after the beginning of the experıment, and the measure-, ments were continued untıl it appeared that the equilibrium state was reäched. In the later experiments the measurements of the beach profiles in the course of beach processes were omitted because the duration time of 20 hours was considered to be almost enough to obtain the equilibrium state.

In order to investigate, furthermore, the changes in the character of breaknng waves were filmed through the side glass wall of the concrete wave tank every one or two hours by a $16 \mathrm{~mm}$ cinecamera. A small wave tank $14 \mathrm{~m}$ long, $0.3 \mathrm{~m}$ wide and $0.4 \mathrm{~m}$ deep, was used to find the relationship between the beach slope and the characters of breaking waves on the fixed bed with the beach slopes of $1^{\circ}$ to $5^{\circ}$ and the deep-water wave steepnesses of 0.02 and 0.04. The profiles of breaking waves on the fixed slopes of beaches were photographed by a camera in the same manner as for those on the movable bed in the concrete wave tank. In this case a plunger type wave generator was used, by which the wave periods are varied from 0.5 sec to 3.5 sec and the wave heights from $1.5 \mathrm{~cm}$ to $4.0 \mathrm{~cm}$ continuously.

\section{RESULTS OF EXPERIMENTS AND CONSIDERATIONS}

\section{PROGRESSION AND RECESSION OF SHORELINE}

The beach profile having a uniform slope of 1 on 10 before testing was deformed with the lapse of time due to wave action and finally reached the equilibrium state after about 15 to 20 hours as shown in Fig. 3 . During that time, the change in the beach profile near the shore line was very rapid for a few hours after the beginning of the test and then became gradual asymptotically or in some cases periodically. In this paragraph, the distance of progression or recession of the shore line until the beach having an inztıal uniform slope reaches the equilıbrium state is treated and 


\section{COASTAL ENGINEERING}

\section{Table 1}

Characters of waves and sands used and data obtained.

\begin{tabular}{|c|c|c|c|c|c|c|c|c|c|c|c|}
\hline Bun No. & $\begin{array}{l}\text { Vave period } \\
T(\text { aec) }\end{array}$ & $\begin{array}{l}\text { Desp-water wave } \\
\text { helght (Ho can) }\end{array}$ & $\begin{array}{l}\text { Deepmarater mave } \\
\text { steepness } \mathrm{H}_{0} / \mathrm{L}_{0}\end{array}$ & $\begin{array}{l}\text { Median dia. } \\
\text { d50 (mo) }\end{array}$ & & $/ d_{50}$ & $\begin{array}{l}\text { Dhstance of shore- } \\
\text { line mov, } x_{\mathrm{SL}}(\mathrm{m})\end{array}$ & $x_{B L} / 2$ & & $\begin{array}{l}\text { Duration } \\
\text { time(hrs) }\end{array}$ & $\begin{array}{l}\text { Investim } \\
\text { gators }\end{array}$ \\
\hline 1 & 1.29 & 2.40 & 0,009 & 0.48 & $5.00 x$ & $10^{1}$ & 0 & 0 & & 6 & Iwagaki- \\
\hline 2 & 1.21 & 2.13 & 0.009 & 0.28 & 7.64 & $"$ & +0.060 & $+3.0 \times 1$ & $10^{2}$ & 9 & 8awaragi \\
\hline 3 & 1.29 & 2.41 & 0.009 & 0.93 & 2.59 & $"$ & +0.096 & +3.7 & $n$ & 5 & $"$ \\
\hline 4 & 3.58 & 20.3 & 0.010 & 0.34 & $5.97 \times$ & $\times 10^{2}$ & +0.54 & +2.6 & $"$ & 12 & Iwagaki- \\
\hline 5 & 2.54 & 9.00 & 0.009 & $n$ & 2.64 & $n$ & +0.43 & +4.3 & $"$ & 18 & Noda \\
\hline 6 & 2.69 & 11.6 & 0.010 & $n$ & 3.40 & $"$ & +0.25 & +2.2 & $"$ & 15 & $"$ \\
\hline 7 & 3.58 & 19.8 & 0.010 & $"$ & 5.81 & $n$ & +0.72 & +3.6 & $"$ & 18 & $n$ \\
\hline 8 & 2.93 & 20.4 & 0.015 & $n$ & 6.00 & $"$ & +0.58 & +4.0 & $n$ & 20 & $"$ \\
\hline 9 & 2.07 & 9.9 & 0.015 & $"$ & 2.90 & $"$ & +0.08 & +1.3 & $n$ & 13 & $n$ \\
\hline 10 & 2.52 & 14.9 & 0.015 & $n$ & 4.38 & $n$ & +0.29 & +2.9 & $"$ & 15 & $"$ \\
\hline 11 & 3.26 & 24.5 & 0.015 & $n$ & 7.20 & $"$ & -1.15 & -6.9 & " & 17 & $"$ \\
\hline 12 & 3.58 & 28.2 & 0,014 & $"$ & 8.28 & $"$ & -0.58 & -2.9 & $n$ & 18 & $"$ \\
\hline 13 & 0.96 & 3.34 & 0.023 & 0.48 & $6.95 \times 1$ & $10^{1}$ & -0.03 & -2.0 & $"$ & 7 & Iwagaki- \\
\hline 14 & 0.98 & 2.66 & 0.019 & 0.28 & 9.53 & $n$ & -0.084 & -6.0 & $n$ & 6 & Sawaregn \\
\hline 15 & 0.97 & 3.67 & 0,025 & 0.93 & 3.95 & $"$ & +0.055 & +3.7 & $"$ & 5 & $"$ \\
\hline 16 & 2.52 & 21.1 & 0.021 & 0.34 & $6.20 \times 1$ & $10^{2}$ & -1.48 & -15.0 & $n$ & 20 & Iwagaki- \\
\hline 17 & 2.19 & 17.6 & 0.023 & $n$ & 5.17 & $n$ & -0.32 & -4.2 & $n$ & 17 & Noda \\
\hline 18 & 3.10 & 30.0 & 0.020 & $"$ & 8.81 & $"$ & -0.57 & -3.8 & $"$ & 20 & $"$ \\
\hline 19 & 2.84 & 25.0 & 0.020 & $"$ & 7.34 & $"$ & -1.45 & -11.4 & $"$ & 20 & $n$ \\
\hline 20 & 3.00 & 20.2 & 0.020 & $"$ & 5.93 & $n$ & -1.54 & -14.8 & $"$ & 20 & $n$ \\
\hline 21 & 3.00 & 29.1 & 0.021 & 0.22 & 1.32 & $n$ & -1.60 & -11.4 & $"$ & 20 & $"$ \\
\hline 22 & 2.50 & 19.0 & 0.020 & $n$ & 8.64 & $"$ & -0.93 & -9.50 & $n$ & 20 & " \\
\hline 23 & 2.20 & 15.9 & 0.021 & $n$ & 7.23 & $n$ & -0.70 & -9.3 & $n$ & 20 & $n$ \\
\hline 24 & 1.86 & 11.3 & 0.021 & $"$ & 5.14 & $"$ & -1.10 & -20.3 & $n$ & 20 & $"$ \\
\hline 25 & 1.56 & 8.0 & 0.021 & $"$ & 3.64 & $"$ & -0.24 & -6.3 & $n$ & 16 & $"$ \\
\hline 26 & 3.00 & 29.1 & 0.021 & 0.34 & 8.55 & $n$ & -0.35 & -2.5 & $"$ & 20 & $"$ \\
\hline 27 & 2.50 & 19.0 & 0.020 & $n$ & 5.59 & $n$ & -0.95 & -9.7 & $"$ & 20 & $n$ \\
\hline 28 & 2.20 & 15.9 & 0.021 & $n$ & 4.67 & $"$ & -0.64 & -8.5 & $n$ & 20 & $"$ \\
\hline 29 & 1.86 & 11.3 & 0.021 & $"$ & 3.32 & $"$ & -0.51 & -9.6 & $"$ & 20 & " \\
\hline 30 & 1.56 & 8.00 & 0.021 & $"$ & 2.35 & " & +0.08 & +2.1 & $n$ & 16 & $"$ \\
\hline 31 & 1.45 & 6.39 & 0.020 & $"$ & 1.88 & $"$ & +0.21 & +6.4 & $"$ & 11 & $n$ \\
\hline 32 & 1.25 & 4.87 & $0 / 020$ & $n$ & 1.43 & $n$ & +0.02 & +0.6 & $"$ & 11 & $"$ \\
\hline 33 & 1.00 & 3.80 & 0.024 & $n$ & 1.12 & $n$ & -0.12 & -0.8 & $"$ & 11 & $n$ \\
\hline 34 & 0.98 & 6.90 & 0.046 & 0.48 & 1.26 & $n$ & -0.16 & -10.0 & $"$ & 12 & $"$ \\
\hline 35 & 2.00 & 23.8 & 0.038 & 0.34 & 6.99 & $n$ & -1.90 & -30.5 & $n$ & 20 & Ivagaka- \\
\hline 36 & 2.40 & 34.9 & 0.039 & $"$ & $1.02 \times 1$ & $10^{3}$ & -1.75 & -19.6 & $"$ & 20 & \\
\hline 37 & 2.20 & 30.0 & 0.040 & $n$ & $8.81 x]$ & $10^{2}$ & -1.74 & -23.0 & $n$ & 20 & $"$ \\
\hline 38 & 2.40 & 35.4 & 0.039 & 0.22 & $1.61 \times]$ & $10^{3}$ & -2.57 & -28.6 & $"$ & 20 & $"$ \\
\hline 39 & 1.90 & 22.0 & 0.039 & $"$ & 1.00 & $n$ & -1.25 & -22.2 & $"$ & 20 & $"$ \\
\hline 40 & 1.65 & 17.3 & 0.041 & " & $7.86 \times 1$ & $10^{2}$ & -1.31 & -30.8 & $"$ & 20 & $"$ \\
\hline 41 & 1.20 & 9.7 & 0.043 & " & 4.41 & $n$ & -0.51 & -22.6 & $"$ & 15 & $"$ \\
\hline 42 & 2.40 & 35.4 & 0.039 & 0.34 & $1.04 \times 1$ & $10^{3}$ & -1.73 & -19.2 & $"$ & 20 & " \\
\hline 43 & 1.90 & 22.0 & 0.039 & " & $6.50 \times 1$ & $10^{2}$ & -1.21 & -21.4 & $"$ & 20 & $n$ \\
\hline 44 & 1.65 & 17.3 & 0.041 & $"$ & 5.10 & $"$ & -0.55 & -12.9 & $"$ & 20 & $"$ \\
\hline 45 & 1.20 & 9.7 & 0.043 & " & 2.85 & $n$ & -0.46 & -20.4 & $"$ & 15 & " \\
\hline
\end{tabular}




\section{LABORATORY STUDY OF SCALE EFFECTS IN TWO-DIMENSIONAL BEACH PROCESSES}

the effects of the wave helght and the sediment size on that distance are discussed. Although, of course, it may be dangerous to derive a general conclusion on the two dimensional beach process only from such shoreline movements, it would be signuficant to adopt the distance of the shoreline movement as a representatıve dimension of beach processes in investıgating the effects of wave herghts and sediment sizes.

The distance $\mathbf{X}_{\mathrm{SL}}$ of shoreline progression (in this case, positive value) or recession (negative value) from the imitial location is a function of the deep-water wave height $\mathrm{H}_{\mathrm{O}}$, the wave perıod $\mathrm{T}$, the still water depth on the horizontal bed in a wave tank $h$, the initial slope of the beach $i_{0}$, the median diameter of sand $\mathrm{d}_{50}$, the specific gravity of sand in water $\mathrm{S}$, the duration time of wave action $t$ and the gravity acceleration $g$. Since the deep-water wave length $\mathrm{L}_{\mathrm{o}}$ is equal to $\mathrm{gT}^{2} / 2 \pi$, the following dimensionless expression is derived by the method of dimensional analysis:

$$
\mathrm{X}_{\mathrm{SL}} / \mathrm{L}_{\mathrm{O}}=\mathrm{f}_{1}\left(\mathrm{~h} / \mathrm{L}_{\mathrm{O}}, \mathrm{H}_{\mathrm{O}} / \mathrm{L}_{\mathrm{O}}, \mathrm{H}_{\mathrm{O}} / \mathrm{d}_{50}, \mathrm{t} / \mathrm{T}, \mathrm{i}_{\mathrm{O}} \mathrm{s}\right) \text {, }
$$

in whlch the effect of fluid viscosity was neglected because it appears that the viscosity effect is much less than those of other factors by the presumption from sediment transport in alluvial channels except the attenuation of waves due to bottom friction. The effect of $h / L_{o}$ Is considered to be neglected as far as the zone of sand movement is limited on the beach slope and $t / T$ can be dropped in the duscussion for the equilibrium state. In addition, the specific gravity of sand in water $S$ is also dropped if constant. Therefore, Eq. (1) is written

$$
X_{S L} / L_{o}=f_{2}\left(H_{0} / L_{0}, H_{o} / d_{50}, i_{o}\right) \text {. }
$$

If the fall velocity $w_{0}$ is taken instead of the median dlameter $d_{50}$ and the specific gravity in water $S$ of sand as a character of sand because of significance of the suspension phenomenon in beach processes, Eq. (2) is replaced as

$$
\mathrm{X}_{\mathrm{SL}} / \mathrm{L}_{\mathrm{o}}=\mathrm{f}_{3}\left(\mathrm{H}_{\mathrm{o}} / \mathrm{L}_{\mathrm{o}}, \sqrt{\mathrm{gH}_{\mathrm{o}}} / \mathrm{w}_{\mathrm{o}}, \mathrm{i}_{\mathrm{o}}\right) \text {. }
$$

Since, furthermore, the fall velocity of a spherıcal sand partıcle with a diameter d50 is expressed

$$
\mathrm{w}_{\mathrm{O}}=\left\{(4 / 3) \operatorname{sgd}_{50} / \mathrm{C}_{\mathrm{D}}\right\}^{1 / 2},
$$

$\mathrm{Eq}$. (3) Is written as follows:

$$
\mathrm{X}_{\mathrm{SL}} / \mathrm{L}_{\mathrm{O}}=\mathrm{f}_{4}\left(\mathrm{H}_{\mathrm{O}} / \mathrm{L}_{\mathrm{O}}, \mathrm{H}_{\mathrm{O}} \mathrm{C}_{\mathrm{D}} / \mathrm{Sd}_{50}, \mathrm{i}_{\mathrm{o}}\right) \text {, }
$$

in which $\mathrm{C}_{\mathrm{D}}$ is the drag coefficıent of a sand partıcle. It is noted that Kurıhara and others (1956) used a factor of $\mathrm{H}_{0} / \mathrm{Sd}_{50}$ in analyzing their data of equilıbrıum beach profiles and beach materıal movements.

Figs. 4a, 4b, 4c and $4 d$ show the relationships between $\mathrm{X}_{\mathrm{SL}} / \mathrm{L}_{\mathrm{O}}$ and $\mathrm{H}_{0} / \mathrm{d}_{50}$ w1th a parameter $\mathrm{H}_{0} / \mathrm{L}_{\mathrm{o}}$ obtained by the plots of data for the inntial beach slope of 1 on 10 based on Eq. (2). The data include the results of experıments by Iwagaki and Sawaragi (1955, 1956) and Kurihara and others (1956) in addition to those by the authors. The similar plots of data by 


\section{COASTAL ENGINEERING}

Saville (1957) for a 1 on 15 inctial beach slope and Rector (1954) for a 1 on 30 slope are shown in Fig. 5. The Rector's data consist of the results for four different sand sizes of $0.22,0.47,0.90$ and $3.44 \mathrm{~mm}$ in median diameter and the wave heights of about 9 to $11 \mathrm{~cm}$. The experimental results by Saville are for a median diameter of $0.22 \mathrm{~mm}$ and the wave helghts of about 45 to $170 \mathrm{~cm}$.

The same data as in Figs. 4a - 4d are plotted based on $\mathrm{Eq}_{\circ}$ (5) in which $\mathrm{H}_{\mathrm{O}} \mathrm{C}_{\mathrm{D}} / \mathrm{Sd} 50$ is introduced instead of $\mathrm{H}_{\mathrm{O}} / \mathrm{d}_{50}$ as shown in $\mathrm{Fig}$. 6 .

The conclusions derived from these figures are as follows:

1. The progression and recession of a shoreline depend not only on the deep-water wave steepness but also on the ratıo of the deep-water wave helght to the medran diameter of sand $\mathrm{H}_{0} / \mathrm{d}_{50}$ or $\mathrm{H}_{\mathrm{O}} \mathrm{C}_{\mathrm{D}} / \mathrm{Sd}_{50}$.

2. It 1 s found that in the case of a 1 on 10 injtial beach slope, the recession of a shoreline will take place whenever the values of $\mathrm{H}_{\mathrm{o}} / \mathrm{d}_{50}$ and $\mathrm{H}_{\mathrm{O}} \mathrm{CD} / \mathrm{Sd} 50$ are larger than approximately 650 and 1100 for a deep-water wave steepness $H_{o} / L_{o}$ of $0.015,250$ and 370 for $H_{O} / L_{o}$ of 0.02 , and 60 and 40 for $\mathrm{H}_{\mathrm{o}} / \mathrm{L}_{\mathrm{O}}$ of 0.04 respectively. In the case $\mathrm{H}_{\mathrm{O}} / \mathrm{L}_{\mathrm{O}}=0.009$, the critical values of $\mathrm{H}_{\mathrm{o}} / \mathrm{d}_{50}$ and $\mathrm{H}_{\mathrm{O}} \mathrm{C}_{\mathrm{D}} / \mathrm{Sd}_{50}$ can not be determsned from the figure because of no enough data for large values of $\mathrm{H}_{\mathrm{o}} / \mathrm{d}_{50}$ and $\mathrm{H}_{\mathrm{o}} \mathrm{C}_{\mathrm{D}} / \mathrm{Sd}_{50}$.

3. The effect of $\mathrm{H}_{\mathrm{O}} / \mathrm{d}_{50}$ or $\mathrm{H}_{\mathrm{O}} \mathrm{C}_{\mathrm{D}} / \mathrm{Sd}_{50}$ on the shoreline movement is very complicated, but it is evident that the sand size affects the beach process with the scale of waves. The variations in the values of $\mathrm{x}_{\mathrm{SL}} / \mathrm{L}_{\mathrm{O}}$ become remarkable with increase in the values of $\mathrm{H}_{\mathrm{O}} / \mathrm{d}_{50}$ or $\mathrm{H}_{\mathrm{O}} \mathrm{C}_{\mathrm{D}} / \mathrm{Sd} 50$.

4. In the case of a 1 on 30 initial beach slope, the variations in the values of $\mathrm{X}_{\mathrm{SL}} / \mathrm{L}_{\mathrm{O}}$ wi.th $\mathrm{H}_{\mathrm{O}} / \mathrm{d}_{50}$ are much more systemat $1 \mathrm{c}$ than in the case of a 1 on 10 beach slope. In this case, also, there exist the critlcal values of $\mathrm{H}_{\mathrm{o}} / \mathrm{d}_{50}$ for the change from progression into recession of a shoreline, whlch depend on the deep-water wave steepness. It appears that the sand size hardly affects the beach process when the values of $\mathrm{H}_{\mathrm{O}} / \mathrm{L}_{\mathrm{O}}$ and $\mathrm{H}_{\mathrm{O}} /$ d50 are smaller than approximately 0.01 and 250 respectively. This tendency is also seen in Fig. 4a for the wave steepness of 0.009 and a 1 on 10 indtial beach slope though the upper value of $\mathrm{H}_{\mathrm{O}} / \mathrm{d}_{50}$ is different.

5. Although there are no sufficient data to discuss for a 1 on 15 inttial beach slope by Saville, it should be noted that they include the data for as large value of $\mathrm{H}_{0} / d_{50}$ as approximately 104 . It is found from these data that even when the deep-water wave steepness is as small as 0.0023 , the recession of a shoreline takes place if $\mathrm{H}_{0} / \mathrm{d}_{50}$ is larger than a certain critical value, and that even if the order of magnitude of $\mathrm{H}_{\mathrm{o}} / \mathrm{d}_{50}$ is changed from $10^{3}$ into $10^{4}$ in the case $H_{0} / L_{O}=0.035$, the absolute value of $\mathrm{X}_{\mathrm{SL}} / \mathrm{L}_{\mathrm{o}}$ does not become large extremely. However, it is sald that more data are needed to derive the correct conclusion.

Generally speaking, it is concluded that the effect of sand size on the beach process is remarkable at least within a certain range of $H_{0} / d_{50}$ or $\mathrm{H}_{\mathrm{O}} \mathrm{C}_{\mathrm{D}} / \mathrm{Sd}_{50}$ including certain critical values of these factors for each value of $\mathrm{H}_{\mathrm{O}} / \mathrm{L}_{\mathrm{O}}$. It $1 \mathrm{~s}$ presumed that this reason is because the mode of sand transport by breaking waves is changed from that of bed-load transport 


\section{LABORATORY STUDY OF SCALE EFFECTS IN TWO-DIMENSIONAL BEACH PROCESSES}

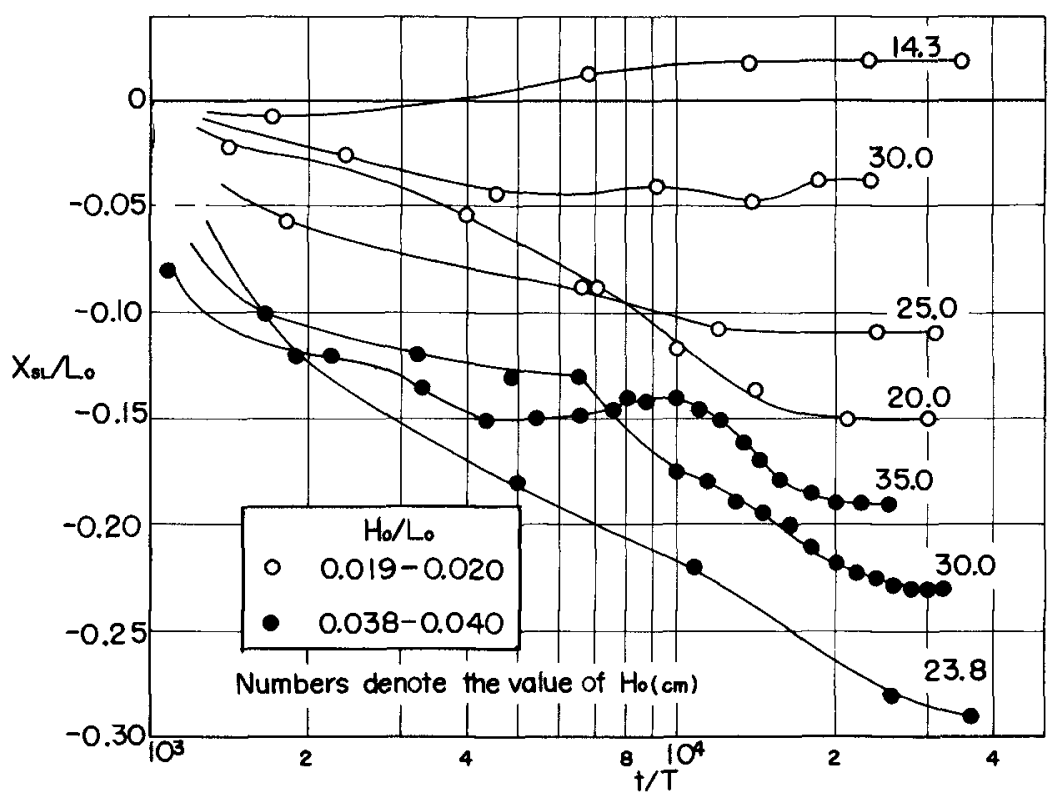

Fig. 3. Dimensionless plots of shoreline movement with time from an initial beach slope of 1 on 10 .
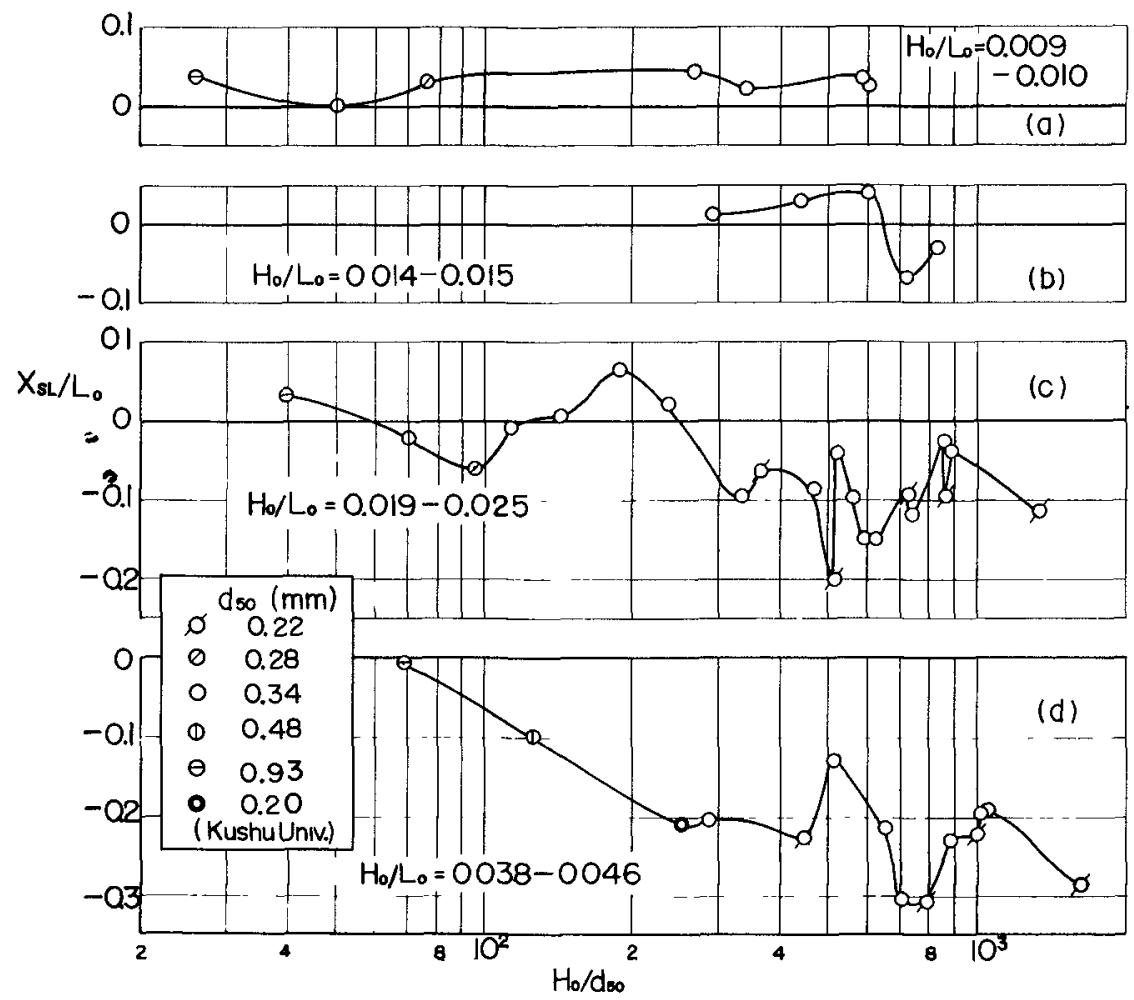

Fig. 4. Dimensionless plots of shoreline movement from an initial beach slope of 1 on 10 to the equilibrium state against the ratio of wave height to sand size. 


\section{COASTAL ENGINEERING}

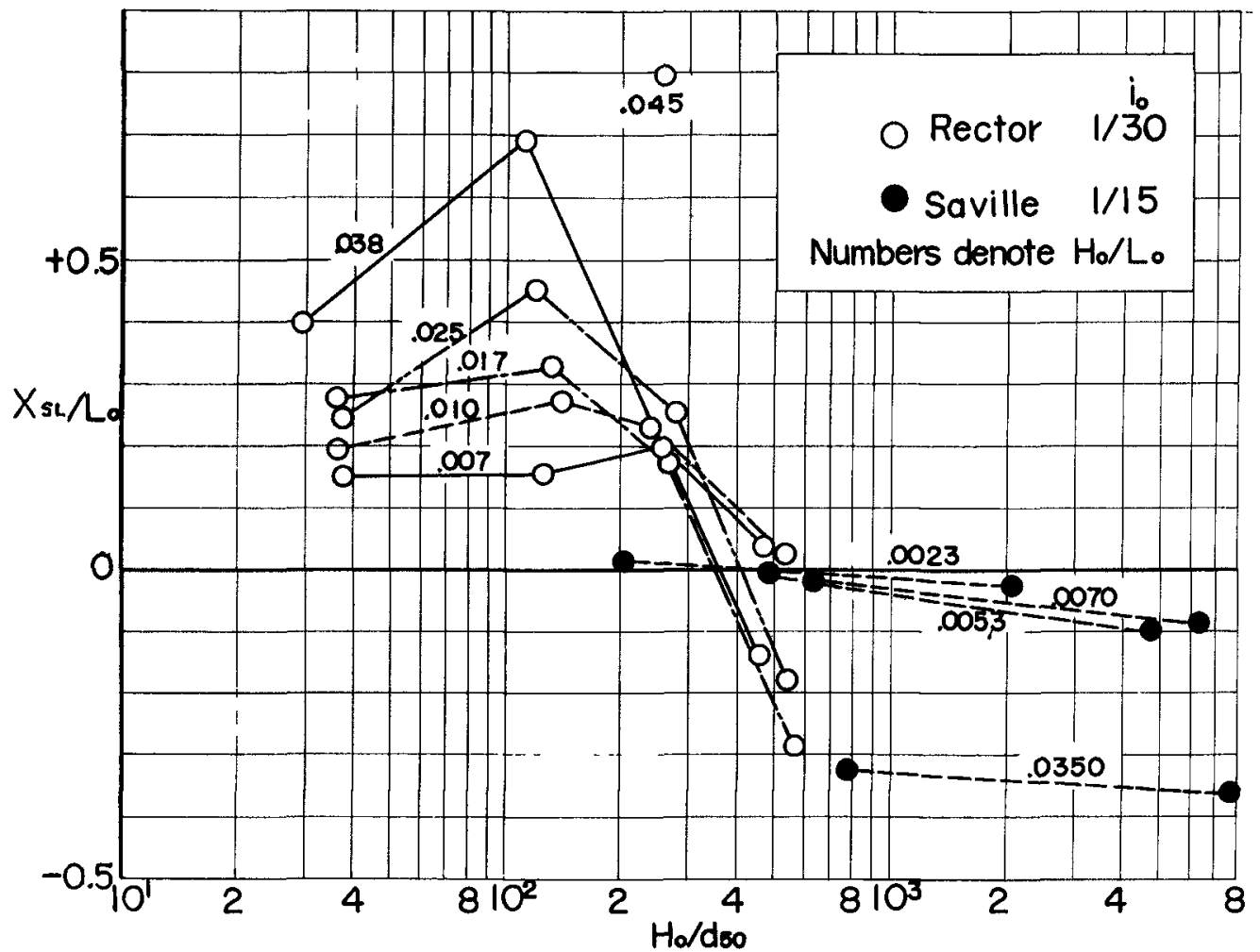

Fig. 5. Dimensionless plots of shoreline movement from initial beach slopes of 1 on 15 and 1 on 30 to the equilibrium state.

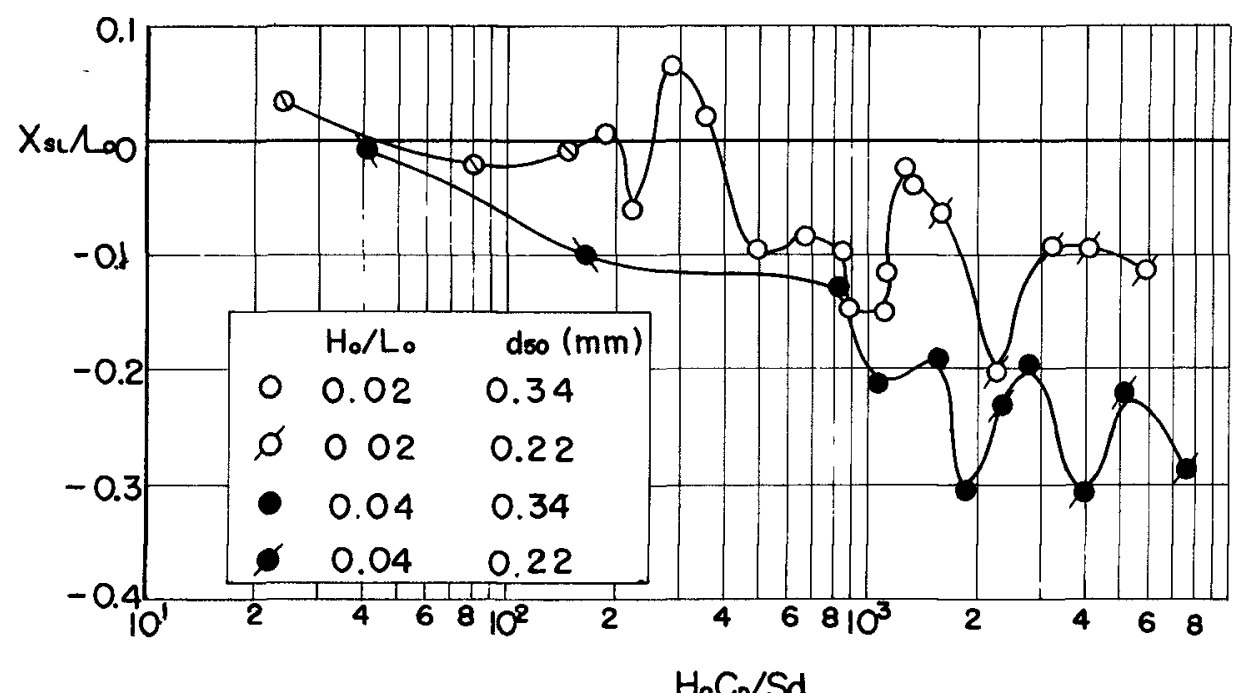

Fig. 6. Dimensionless plots of shoreline movement from an initial beach slope of 1 on 10 to the equilibrium state against $\mathrm{H}_{0} \mathrm{CD} / \mathrm{Sd}_{50}$. 


\section{LABORATORY STUDY OF SCALE EFFECTS IN}

TWO-DIMENSIONAL BEACH PROCESSES
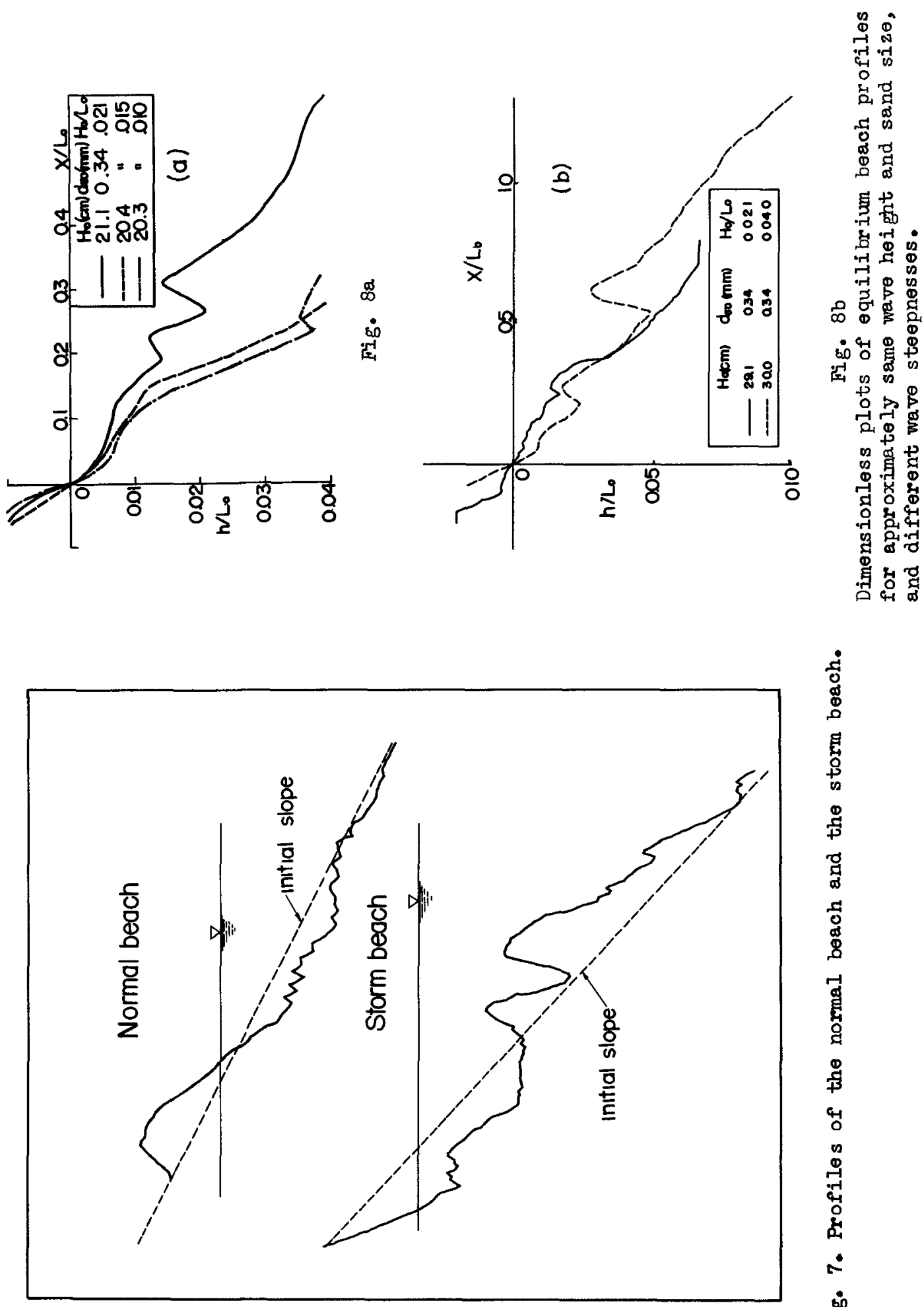

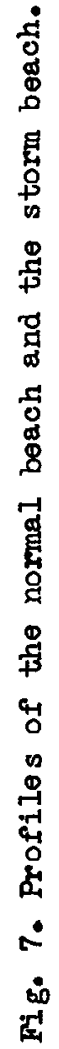




\section{COASTAL ENGINEERING}

for small values of $\mathrm{H}_{0} / \mathrm{d}_{50}$ or $\mathrm{H}_{0} \mathrm{C}_{\mathrm{D}} / \mathrm{Sd} 50$ into that of suspended-load transport for large values of $\mathrm{H}_{0} / \mathrm{d}_{50}$ or $\mathrm{H}_{0} \mathrm{C}_{\mathrm{D}} / \mathrm{Sd}_{50}$.

\section{EQUILIBRIUM BEACH PROFILES}

A laboratory study by Johnson (1949) indıcated that equilibrıum beach profiles are classified those of the "normal" or "ordinary" beach, where there are no longshore bars, and of the "storm" beach, whlch is characterized by the development of longshore bars, as shown in Fig. 7. Rector (1954) made an effort to express the dimensionless equilibrıum beach profile using the deep-water wave length $\mathrm{L}_{0}$ as a function of $\mathrm{H}_{0} / \mathrm{L}_{0}$ and $d 50 / \mathrm{L}_{0}$. Watts (1954) made experiments to investigate the effect of varing wave periods on equilıbrium beach profiles with an inltial beach slope of 1 on 20 . However, all of these experiments were of very small scales including the tests in Japan, compared with actual beaches. The results of the large scale experıments made by Saville (1957) showed the fact that even when the deep-water wave steepness is very small, storm beaches having longshore bars appear in the equilibrium state, which are not seen in the common experiments of small scale. From this reason, the scale effect on the equilibrium beach profile is considered by dividing the experimental results into three following cases:

Case when wave heights and sand slzes are same and wave steepnesses are different - Figs. 8a and 8b show the dimensionless plots of the equilibrium beach profiles, whlch are expressed by the ratios of a distance from the shoreline $X$ and the water depth $h$ to the wave length $L_{0}$, for the wave helghts of approxımately $21 \mathrm{~cm}$ and $30 \mathrm{~cm}$, a sand size of $0.34 \mathrm{~mm}$ in median diameter and the different wave steepnesses. It is found from the se figures that the wave steepness affects the equillbrium beach profile remarkably when $\mathrm{H}_{0} / \mathrm{d}_{50}$ is constant. Furthermore, it should be noted that the beach profiles in the case $\mathrm{H}_{0} / \mathrm{L}_{0}=0.021$ are of the storm beach though this value of the wave steepness is smaller than the critical value 0.025 0.03 determined by Johnson.

Case when wave steepnesses and sediment sizes are same and wave heights are different - Fig. 9 shows comparisons of the equilibrium beach profıles for approxımately constant wave steepnesses $0.021-0.024$, a sand size of $0.34 \mathrm{~mm}$ in median diameter and varlous wave helght. It is disclosed from the figure that the equilibrium beach profile depends not only on the wave steepness and sediment size but also on the wave helghts. In the cases $\mathrm{H}_{\mathrm{O}}=21.1 \mathrm{~cm}$ and $29.1 \mathrm{~cm}$, the storm beaches were formed, and in the case $\mathrm{H}_{\mathrm{O}}=3.8 \mathrm{~cm}$ the normal beach was developed though the wave steepness were almost same, and also the sedıment size was constant. In the case $H_{0}$ $=11.3 \mathrm{~cm}$ it is undecided whether or not. Such differences in the equilibrıum beach profile were already indıcated by Saville (1957).

Case when wave steepnesses and wave heights are same and sand sizes are different - The equilibrium beach profiles are shown in Figs. 10a, 10b and $10 \mathrm{c}$ for two different sand sizes $\left(\mathrm{d}_{50}=0.34 \mathrm{~mm}\right.$ and $\left.0.22 \mathrm{~mm}\right)$, same wave helghts of $29.1 \mathrm{~cm}, 15.9 \mathrm{~cm}$ and $11.3 \mathrm{~cm}$ and same wave steepness of 0.021 . As shown in Fig. 10a, the longshore bars of approxımately same scale are formed and the profiles are very simllar except in the vicincty of the beachface in splte of different sand slzes in the case of a large wave height of $29.0 \mathrm{~cm}$. With decrease in the wave height as shown in Fig. 10b, longshore 


\section{LABORATORY STUDY OF SCALE EFFECTS IN TWO-DIMENSIONAL BEACH PROCESSES}

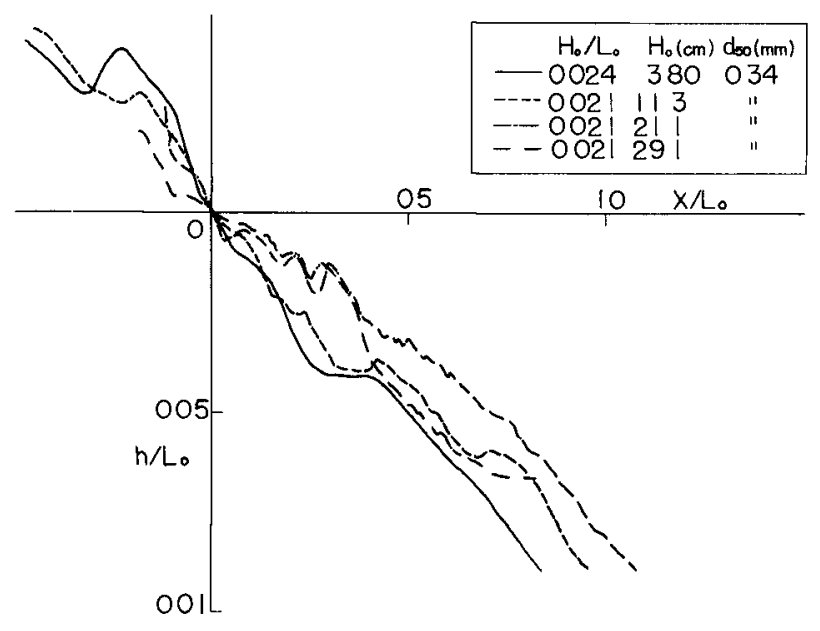

Fig. 9. Dimensionless plots of equilibrium beach profiles for approximately same wave steepness and sand size, and different wave heights.

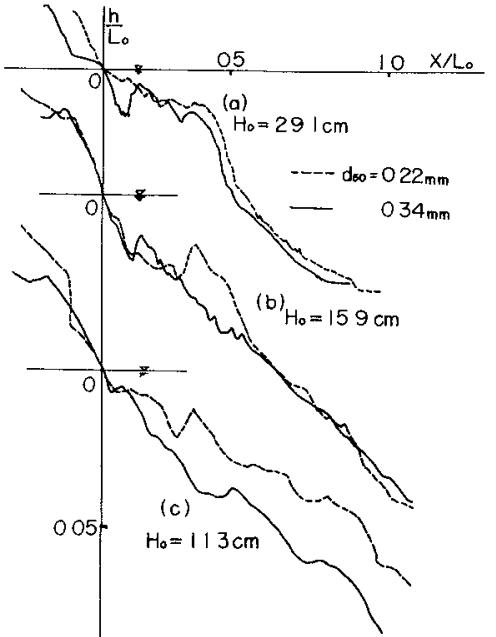

Fig. 10. Dimensionless plots ، equilibrium beach profilos for same wave hei ghts and constan" wave steepness of 0.021 , and, ferent sand sizes.

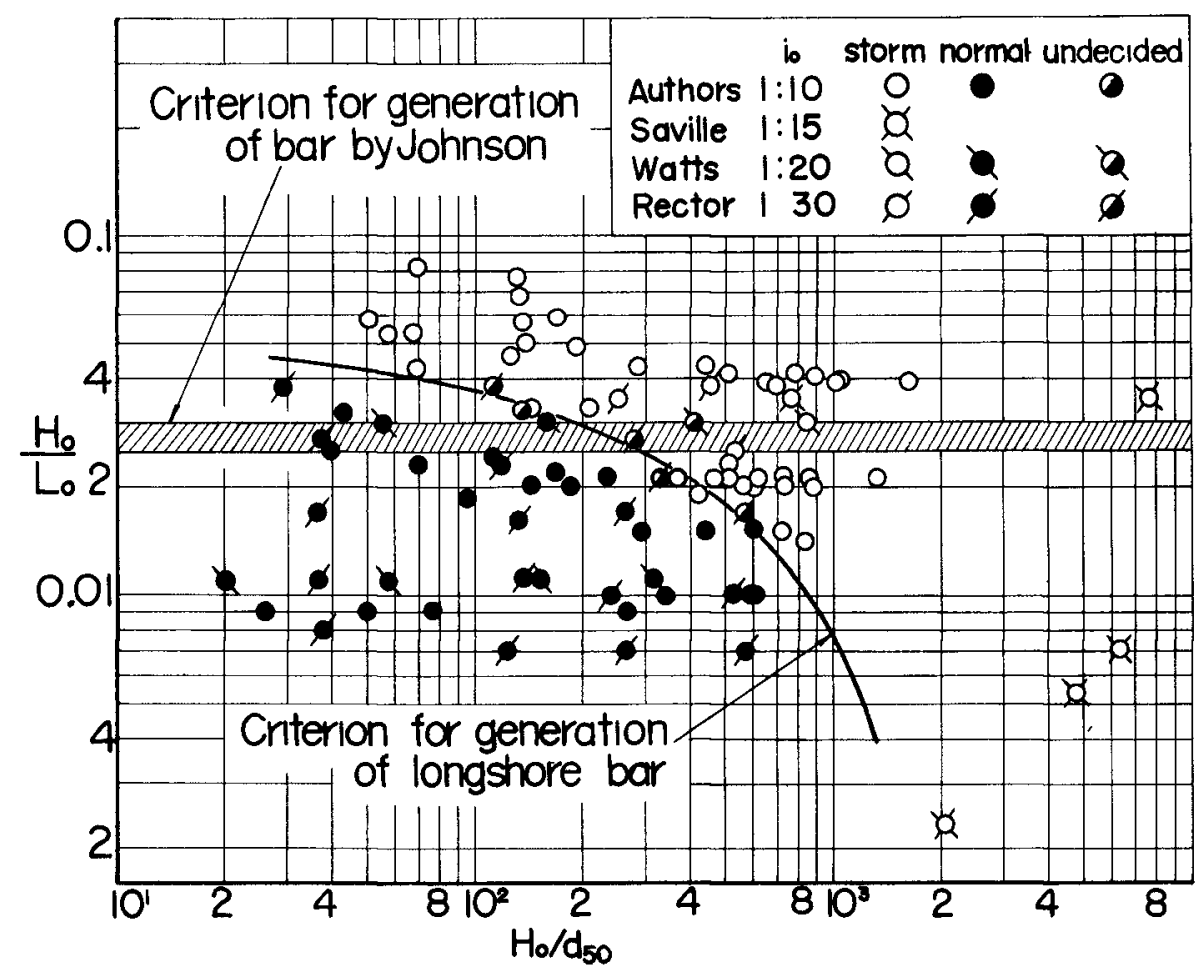

Fig. 11. Criterion for generation of longshore bars. 


\section{COASTAL ENGINEERING}

bars in the coarser sand $\left(\mathrm{d}_{50}=0.34 \mathrm{~mm}\right)$ are reduced, thus the profiles are different in the inshore zone. Further decrease in the wave helght produces the completely different profiles for the difference of sand size as shown in Fig. 10c. A longshore bar ls still formed in the finer sand, and on the other hand, in the coarser sand it almost disappears. These facts can also be found in the results of experiments four different sand sizes and same waves by Watts (1954).

\section{CRITERION FOR GENERATION OF LONGSHORE BARS}

In the foregoing section, it has been found that the equilibrium beach profile depends not only on the deep-water wave steepness but also on the wave height and the sand size. From this fact it is presumed that a limitation between the storm beach and the normal beach, which is a criterion for generation of longshore bars, can also be expressed by the deep-water wave steepness $\mathrm{H}_{\mathrm{O}} / \mathrm{L}_{\mathrm{o}}$ and the ratio $\mathrm{H}_{\mathrm{O}} / \mathrm{d}_{50}$ or $\mathrm{H}_{\mathrm{O}} \mathrm{C}_{\mathrm{D}} / \mathrm{Sd}_{50}$. Fig. 11 shows the log$\mathrm{log}$ plots of experimental data by the authors and other investigators with the ordinate of $\mathrm{H}_{\mathrm{o}} / \mathrm{L}_{0}$ and the absclssa of $\mathrm{H}_{\mathrm{o}} / \mathrm{d}_{50}$, in which the data are distinguzshed between the normal beach and the storm beach, and plotted for each intial beach slope. In the figure the boundaries between the normal beach and the storm beach have been drawn, the one is by Johnson and the other is that proposed by the authors under the assumption that the initial beach slopes are independent of equilibrium beach profiles, especially the generation of longshore bars.

It is evident from this figure that when the value of $\mathrm{H}_{\mathrm{o}} / \mathrm{d}_{50}$ is smaller than a certain value, the critıcal value of $\mathrm{H}_{0} / \mathrm{L}_{0}$ proposed by Johnson is approximately valid; however, with increase in the value of $\mathrm{H}_{\mathrm{o}} /$ d50 the critıcal wave steepness becomes small rapidly. Thls fact indicates that at the beach being constıtuted by fine sand and where large waves attack, the storm beach is formed and longshore bars appear even when the deep-water wave steepness is considerably small. It is very significant that the limitation between the storm beach and the normal beach is expressed by $\mathrm{H}_{\mathrm{o}} / \mathrm{d}_{50}$ and $\mathrm{H}_{\mathrm{o}} / \mathrm{L}_{\mathrm{O}}$.

\section{CHANGES IN CHARACTERISTICS OF BREAKING WAVES DURING BEACH PROCESSES}

It is well known that there are generally two types of breaking waves, which are called spllling breakers and plunging breakers. Laboratory studies by Iversen (1952) and Hayami (1955, 1958) indicated that the limitation between both types of breakers can be expressed by the deep-water wave steepness and the beach slope (F1g. 12). The critical wave steepness theory is based on the idea that the types of breakers are much related with the beach process; that is, beach erosion will occur with spilling breakers and beach accretion will take place whth plunging breakers.

Since, however, the experimental results shown in Fig. 12 are for the fixed beds of uniform slopes, the question arlses whether the same results can be applied to the beach of a movable bed or not. In F1g. 12, furthermore, the limitation is not clear when the bed slope is very small. For example, according to this figure plunging breakers appear whenever the deepwater wave steepness is 0.02 , and thus beach accretion is to take place in thys case. However, it is seen in Fig. 4c that beach erosion occurs even when $\mathrm{H}_{\mathrm{o}} / \mathrm{L}_{\mathrm{o}}$ is approximately 0.02 . It is very difficult, therefore, to 


\section{LABORATORY STUDY OF SCALE EFFECTS IN TWO-DIMENSIONAL BEACH PROCESSES}

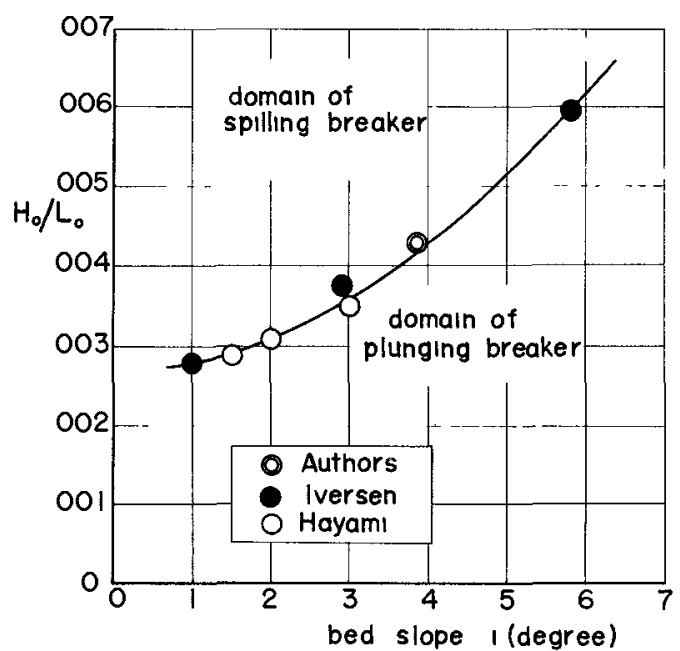

Fig. 12. Limitation betweon spilling breakers and plunging breakers.

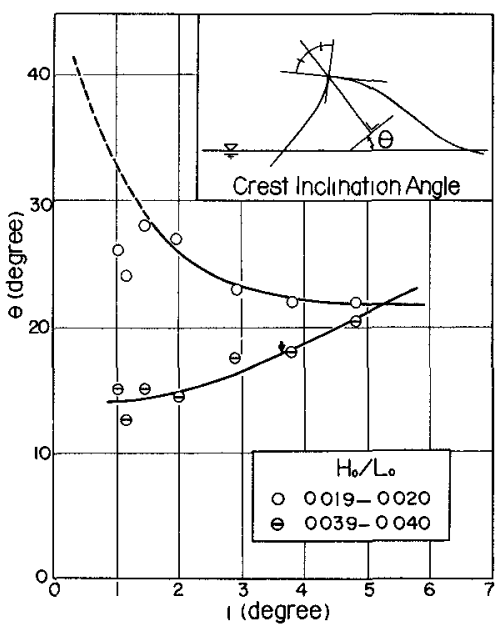

Fig. 13. Relationships between crest inclination angle of breakers and bed slope for fixed bed.

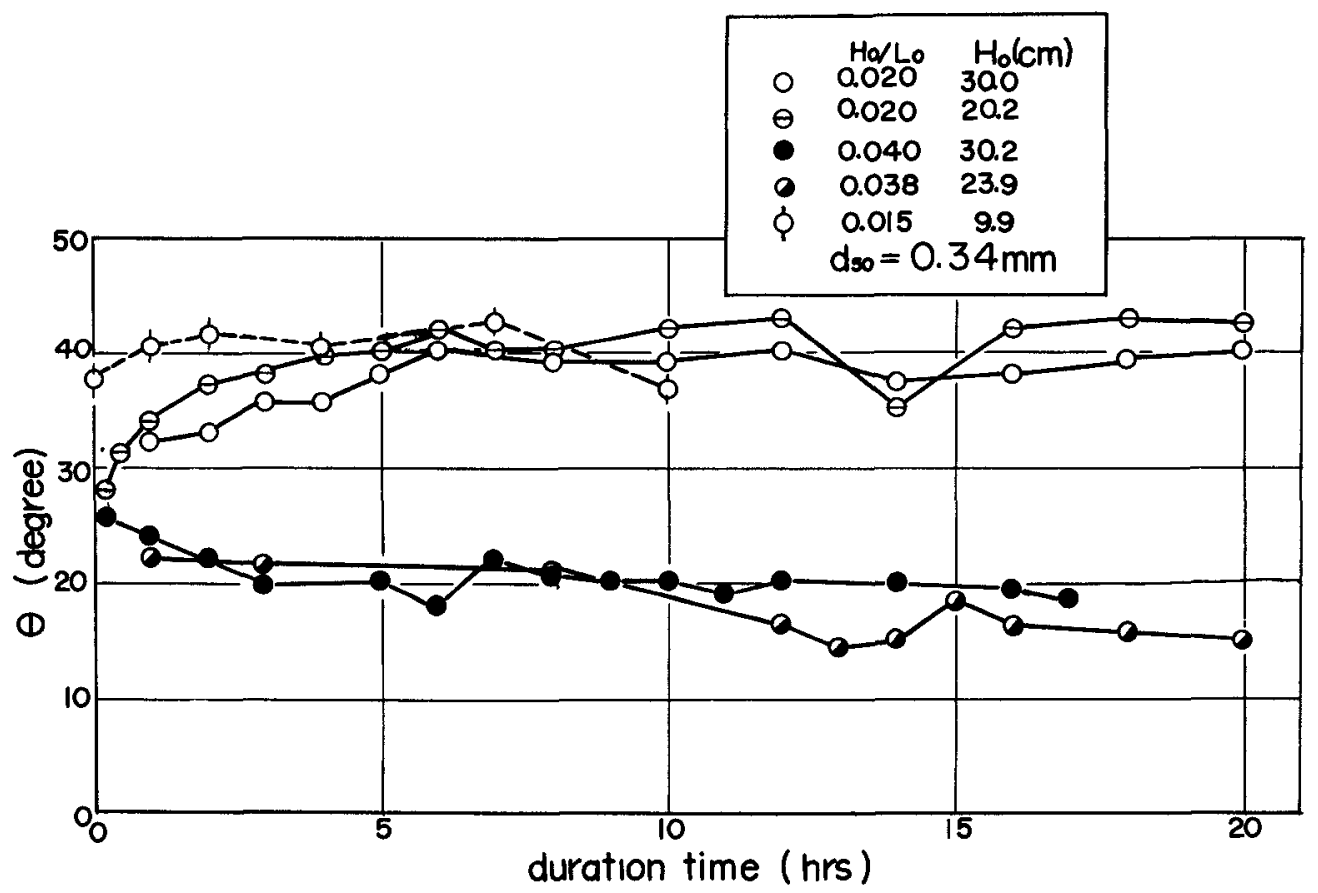

Fig. 14. Progressive changes in crest inclination angle of breakers with time for various wave steөpnesses. 


\section{COASTAL ENGINEERING}

connect directly the critıcal wave steepness theory with the characters of breakıng waves on the movable bed. From this reason, an effort is made in ınvestigatıng the relationship between profiles of breakers and beach processes in this section.

As a quantitative expression for the profile of a breaking wave, the angle $\theta$ is treated, which 1 s an angle between a bisector of the crest angle of a breakıng wave and a perpendlcular lıne as shown in Fig. 13. This crest inclination angle $\theta$ is very convenıent to discuss asymmetricity of a breakıng wave; that $1 \mathrm{~s}, \theta=00$ if waves at breakıng are symmetrıc completely, and $\theta=45^{\circ}$ if they are extremely asymmetrıc. It 1 s considered that the crest inclination angle becomes close to $45^{\circ}$ in plunging breakers and to $0^{\circ}$ in spllling breakers.

First, in order to disclose the relatıonshıps between the crest inclination angle $\theta$ and the bed slope 1 , an experıment was made by using a small wave tank with a flxed tıltıng beach slope. Fig. 13 shows the relationship in the cases $\mathrm{H}_{\mathrm{o}} / \mathrm{L}_{\mathrm{o}}=0.02$ and 0.04 . From this figure the followings are made clear:

1. The angle $\Theta$ is changed with the slope 1 even if the deep-water wave steepness $\mathrm{H}_{\mathrm{O}} / \mathrm{L}_{\mathrm{O}}$ Is constant.

2. An arrow in Flg. 13 corresponds to the crltical beach slope for the wave steepness of 0.04 decided by Iversen and Hayam. Therefore, the regions where the beach slopes are smaller and larger than the critical belong to those of splllıng breakers and plungıng breakers respectıvely.

3. In the case $\mathrm{H}_{\mathrm{o}} / \mathrm{L}_{\mathrm{O}}=0.02$, the angle $\theta$ increases w th decrease In the slope 1. However, the experimental results show the opposite tendency when the slope is smaller than $1.5^{\circ}$. It is considered that this opposite tendency may be caused by the caplllary effect because of small waves. It was observed that breaknng waves in this case were of the plunging type independently of the slope.

Next, the progressive changes in the crest inclination angle $\theta$ with tıme durıng beach processes are shown in Fig. 14. It 1s found from this figure that tha angle $\theta$ seems to reach a constant value for each wave steepness finally independently of an inıtıal angle corresponding to an inltial beach slope of 1 on 10. The duration time for the angle $\theta$ to become constant is much shorter than that for the beach to reach the equilibrium state.

In the case $\mathrm{H}_{\mathrm{O}} / \mathrm{L}_{\mathrm{o}}=0.04$, as shown In Fig. 14, the angle $\theta$, which was approximately $27^{\circ}$ on the inztial beach slope of 1 on $10\left(1=5^{\circ} 43^{\prime}\right)$ after beginning of the experıment, became 190_ $20^{\circ}$ at the equilibrium state. This final crest inclination angle agrees falrly with that at the beach slope $1=$ $4^{\circ}-4.5^{\circ}$ in Fig. 13 whlch corresponds approximately to the critical wave steepness theory of Iversen and Hayamn. In the case $\mathrm{H}_{\mathrm{o}} / \mathrm{L}_{\mathrm{O}}=0.02$, the final crest inclination angle was approximately $40^{\circ}$ as shown 1 n Fig. 14, but the beach slope 1 corresponding to $\theta=40^{\circ}$ can not be obtalned precisely from Flg. 13 and it is impossible to compare that value with that by the critical wave steepness theory because there are no data for the keach slope less than $1^{\circ}$ in Fig。 12 . 


\section{LABORATORY STUDY OF SCALE EFFECTS IN TWO-DIMENSIONAL BEACH PROCESSES}

\section{CONCLUSIONS}

It Is concluded from the results of laboratory tests on the two dimensional beach process that:

1. Two dimensional beach processes are influenced not only by the deep-water wave steepness but also by the scale of waves and the sand sizes.

2. The influence of sand sizes on the beach process is not remarkable when the deep-water wave steepness Is smaller than approximately 0.01 and, in additıon, the ratıo of the wave helght to the sand size is smaller than a certain value for each wave steepness.

3. Equilıbrium beach profiles are also influenced not only by the deep-water wave steepness but by the wave height and the sand size.

4. The limitation between the normal beach and the storm beach, which is a criterion for generation of longshore bars, can be expressed by the deep-water wave steepness and the ratio of the wave helght and the sand size.

5. The crest inclinatıon angle of breakıng waves approaches a certain value for each deep-water wave steepness with the formation of the equilibrium beach profile independently of an ınıtıal beach slope. This value of the angle agrees falrly with that of breakıng waves on the fixed bed of the critical beach slope based on the limitation between spllling breakers and plunglng breakers when the deep-water wave steepness 1 s 0.04 .

\section{ACKNOWLEDGEMENTS}

The authors wish to express their great appreciations to Prof. T. Ishlhara for his encouragement to perform this study and to Assist. Prof. Y. Tsuchıya, Messrs. Y. Kawasakı, T。 Ibo, J. Sakal and M. Kuge for assıstıng the experıments and preparıng this paper.

\section{REFERENCES}

Hayamı, S., Ishıhara, T. and Iwagaki, Y. (1953). Some studıes on beach erosıons: Disaster Preventıon Research Instıtute, Kyoto Unıversıty, Bulletın No. $5,29 \mathrm{pp}$.

Hayamı, S. (1955). Mechanlsm of breakers (II), Proc. of 2nd Conference of Coastal Englneerıng in Japan, pp. 13-15 (1n Japanese).

Hayamı, S. (1958). Types of breakers, wave steepness and beach slope, Coastal Englneerıng in Japan, Vol. 1, pp. 2l-24.

Iversen, H. W. (1952). Waves and breakers in shoaling water, Proc. of 3rd Conference on Coastal Englneerıng, pp. 1-12.

Iwagakı, Y. and Sawaragı, T. (1955). Experıments on equılıbrıum slopes of beaches and sand movement due to breakers, Proc. of 2nd Conference of Coastal Englneerıng ın Japan, pp. 99-105 (in Japanese).

Iwagakı, Y. and Sawaragı, T. (1956). Some problems on the equılıkrıum slopes 


\section{COASTAL ENGINEERING}

of beaches, Disaster Preventıon Research Instıtute, Kyoto University, Bulletın, Memorıal Issue of 5th Anniversary, pp. 233-240 (in Japanese).

Iwagakı, Y. and Sawaragi, T. (1958). Experımental study on the equilibrium slopes of beaches and sand movement by breaker, Coastal Engineerıng in Japan, Vol. 1, pp. 75-84.

Iwagaki, Y. and Sawarag1, T. (1960). A new method for estımation of the rate of littoral sand drift, Proc. of $7 \mathrm{th}$ Conference of Coastal Engineerıng in Japan, pp. 59-67 (1n Japanese).

Iwagaki, Y. and Noda, H. (196la). Scale effects in hydraulic models for beach process, Disaster Prevention Research Institute, Kyoto Universıty, Annuals No. 4, pp. 210-220 (In Japanese).

Iwagaki, Y. and Noda, H. (1961b). A study of scale effects in experıments for beach processes, Proc. of 8th Conference of Coastal Engineering in Japan, pp. 139-143 (in Japanese).

Johnson, J. W. (1949). Scale effects in hydraulic models involving wave motion, Trans. Amer. Geophys. Union, Vol. 30, pp. 517-525.

Kurıhara, M., Shinohara, K., Tsubaki, T. and Yoshihara, M. (1956). Sand movement on beaches by waves, Proc. of 3rd Conference of Coastal Engineering in Japan, pp. 151-159 (1n Japanese).

Rector, R. L. (1954). Laboratory study of equilibrıum profiles of beaches, Beach Erosion Board, Tech. Memo., No. 41, 38 pp.

Saville, T. Jr. (1957). Scale effects in two dımensıonal beach studıes, Proc. of 7th General Meeting, I. A. H. R., Vol. I, pp. A3.1-A3.10.

Sawaragi, T. and Murakamı, T. (1957). On the estımatıon of the rate of littoral sand drift, Proc. of 4th Conference of Coastal Engineerıng in Japan, pp. 41-49 (in Japanese).

Scott, T. (1954). Sand movement by waves, Beach Erosion Board, Tech. Memo., No. $48,37 \mathrm{pp}$.

Shinohara, K., Tsubaki, T., Yoshitake, M. and Agenorı, Ch. (1958). Sand transport along a model sandy beach by wave action, Coastal Engineerıng in Japan, Vol. 1, pp. 111-130.

Watts, G. M. (1954). Laboratory study of effect of varying wave perıods on beach profiles, Beach Erosion Board, Tech. Memo., No. 53, 19 pp。 